\title{
Učitelské sdílení profesních zkušeností - aktuální pohled z českých škol
}

\author{
Irena SmetáčKová, Anna Vozková
}

\begin{abstract}
Abstrakt: Cílem príspèvku je predstavit sdileni profesnich zkušenosti mezi učiteli a ukázat jeho úlohu v rámci profesního rozvoje. Výzkumy ukazuji, že sdileni posiluje (sebe) reflexi vyučujicich a prohlubuje pozitivni kolegiálni vztahy a spolupráci v učitelských sborech. Zároveň však $k$ nèmu existuji určité bariéry a negativni postoje. Článek predstavuje výsledky výzkumu, který proběhl v českém prostředi. Jeho zámèrem bylo zjistit, jaké zkušenosti maji čestí vyučujici s profesnim skupinovým sdilenim a jaké výhody a nevýhody u nèj vnimaji.

Metody: Výzkum probihal formou on-line dotaznikového šetřeni mezi vyučujicimi regionálního školství. Dotazník obsahoval 20 položek. Žádost o vyplnèní byla rozeslána na všechny školy registrované v rejstrúku škol. Dotaznik kompletnè vyplnilo 2377 osob. Následná analýza zahrnovala deskriptivni statistiku, testováni rozdili mezi podskupinami podle osobni zkušenosti s profesnim sdilenim a kvalitativni metody jako např. otevrené kódování.

Výsledky: $43 \%$ vyučujicich mělo zkušenost s nějakým typem pravidelného skupinového sdileni zkušeností, pouze 4,5\% mélo zkušenost se supervizi, $1 \%$ s intervizí. $33 \%$ téchto setkání bylo vedeno externisty a $56 \%$ bylo povinných. Jako nejvètši prínosy setkáni byly uvádèny vzájemná motivace, inspirace a budováni společné vize. Hlavni prekážky pro sdileni byly nedostatek financí, zavaleni jinými úkoly a obava sdílet problémy.

Závèry: Vètšina zahrnutých vyučujicich (57\%) nemèla přistup $k$ profesnimu sdileni, pritom ale $61 \%$ by mélo o zavedeni sdileni zájem. Osobni zkušenost s ním se navic ukázala jako düležitý faktor pro hodnoceni překážek a př́nosů. Vyučujicí, kteři mèli osobni zkušenost se sdilenim, hodnotili všechny prínosy jako důležitějši a prekážky jako méně významné.
\end{abstract}

Klíčová slova: profesni sdileni, supervize, vyučujicí, kolegialita, učitelský rozvoj

\section{ÚvOD}

Učitelství je tradičně vnímáno jako spiśe individualizované povolání, $\mathrm{v}$ jehož hlavní části (práce $s$ žáky) jsou vyučující odkázáni pouze sami na sebe. Aby školy byly úspěšné při vzdělávání svých žáků, potřebují úspěšné vyučují- cí. Je proto logické, že se postupně více pozornosti přesouvá na učitele a učitelské kolektivy. Zesilují trendy akcentující týmovou spolupráci a profesní rozvoj založený na kolegialitě, který by měl vést k profesnímu růstu vyučujících, lepšímu zvládání jejich pracovní zátěže a řešení obtížných situací (Kasíková \& Dubec, 
2009; Starý et al., 2012; Staempfli \& Fairtlough, 2019). V rámci těchto trendů se stále častěji i v českém prostředí začínají objevovat nabídky mentoringu, supervize a podobných aktivit (např. Lazarová, 2010; Michek, 2016).

Článek nabízí přehled poznatků o sdílení profesních zkušeností ${ }^{1}$ vyučujících coby specifické formě učitelského profesního rozvoje. Kromě zahraničních a nečetných českých zdrojů předkládáme také výsledky české studie ${ }^{2}$ zaměrující se na vnímané nevýhody a překážky, které od profesního sdílení mohou vyučující odradit, ale i na pozitiva, která může společné sdílení v rámci učitelské profese přinést.

\section{Profesní uČItelsKÝ ROZVOJ}

\section{A JEHO SOUČÁSTI}

Průběžné změny $\mathrm{v}$ podmínkách a nárocích učitelství vytvářejí nutně z profesního rozvoje dlouhodobý proces. V některých státech (např. USA - New York) je toto pojetí podpořeno tím, že učitelé nezískávají po ukončení vysokoškolského vzdělávání trvale platné osvědčení, ale musí každých několik let podstoupit určité penzum hodin profesního rozvoje, aby jim byla obnovena li- cence $\mathrm{k}$ učení (např. 175 hodin za 5 let). To reflektuje přesvědčení, že v učitelské profesi (stejně jako v jiných profesích) by mělo být samozřejmostí zlepšování vlastních schopností a soulad s aktuálními poznatky (Torff \& Sessions, 2008). ${ }^{3}$

Jak upozorňuje Avalos (2011), učitelský profesní rozvoj bývá často vnímán jako proces, kdy se učitelé individuálně vzdělávají v tom, jak lépe učit a jak správně př̀edávat své poznatky. Novější pojetí se shodují v tom, že je nutné, aby rozvoj probíhal v kolektivu a aby vyučující měli možnost komunikovat s dalšími kolegy, a současně že se jedná o komplexní proces, který zahrnuje různé elementy a faktory: „Učitelský profesní rozvoj je komplexní proces, který vyžaduje kognitivní a emoční zapojení vyučujícího individuálně i kolektivně, dále vyžaduje jeho kapacitu a ochotu prozkoumávat, kde on sám stojí, jaká jsou jeho přesvědčení, a hledat vhodné alternativy pro zlepšení nebo změnu." (Avalos, 2011, s. 10)

Napříć různými prúístupy můžeme identifikovat následující charakteristiky, které by měl učitelský profesní rozvoj zahrnovat, aby byl efektivní (Evans, 2002; Torff \& Sessions, 2008; Avalos, 2011; McComb \& Eather, 2017):

\footnotetext{
${ }^{1}$ Sdílení profesních zkušeností je v textu někdy kvůli přehlednosti zkráceno např. na sdílení zkušeností, profesní sdílení nebo pouze sdílení.

${ }^{2}$ Příspěvek byl podpořen Technologickou agenturou ČR (Projekt Supervize - prevence učitelského vyhoření, TAČR TL01000399).

${ }^{3}$ V ČR je povinnost dále se vzdělávat stanovena zákonem č. 563/2004 Sb., a to v rámci DVPP (Další vzdělávání pedagogických pracovníků). To probíhá podle uvedeného zákona formou akreditovaných kurzů nebo samostudiem. V české terminologii není jednoznačný vztah mezi DVPP a profesním rozvojem - může se jednat o synonyma, nebo je rozvoj nadřazený pojem (Lazarová \& Prokopová, 2004).
} 
1. v dostatečné míře by měl zahrnovat spolupráci a zpětnou vazbu od kolegů (formálně i neformálně $)$; 2. jako klíčová se jeví možnost reflektovat a zlepšování schopnosti sebehodnocení; 3. zahrnuje nejen rozvoj vědomostí a dovedností, ale také změny $\mathrm{v}$ postojích, emocích, motivaci nebo profesní roli; 4. je dlouhodobý, různorodý (zahrnuje více metod) a smysluplně zapojený do školního života; 5. umožňuje učitelům se aktivně zapojit a zakomponovat nové metody do praxe.

Většina autorů se shoduje, že se jedná o komplexní proces zahrnující různé oblasti. Pro ilustraci můžeme zmínit model autorské dvojice Ross \& Bruceová (2007). Ten je založen na principu změny, která se soustředí především na učitelské sebehodnocení. To zahrnuje tři procesy: sebe-pozorováni učitelovy úspěšnosti, sebe-posouzeni naplňování jeho cílů a reagováni nebo interpretaci toho, jak byly cíle naplněny a jak je $s$ tím jedinec spokojen. Klíčovým faktorem ve všech třech procesech je vliv kolegů, kteří vyučujícím mohou pomoci soustředit se na důležité aspekty praxe a poskytnout zpětnou vazbu, která bud' podpoří, nebo naopak bude oponovat sebehodnocení učitele. Nejen ze zmíněného modelu profesního rozvoje, ale i z dalších existujících (např. Clarke \& Hollingsworth, 2002; Guskey, 2002) vyplývá význam kolegiálních vztahů.

\section{UČITELSKÁ KOLEGIALITA}

Komunikace $s$ druhými osobami slouží $\mathrm{v}$ rámci profesního rozvoje řadě účelů. Ty jsou částečně závislé na tom, zda se jedná o osoby v asymetrických, nebo symetrických pozicích a zda osoby náleží ke škole, či jsou externí/cizí. $S$ oporou v práci Michka (2016) a dalších (např. Starý et al., 2012; Píšová et al., 2013) lze tvrdit, že současná podoba profesního rozvoje $\mathrm{v}$ českých školách využívá nejčastěji následující konstelaci - vně školy a asymetrická pozice (vyučující se účastní na akce mimo školu, kde mu někdo přednáší). Prostor symetrických a vnitřních vztahů, tedy prostor kolegiality, často není plně využíván (Kasíková \& Dubec, 2009).

Kolegialita pro nás představuje tři kvality: rovnost, profesionalitu a vzájemnost. Kolegiální vztahy jsou tak více než na osobní sympatii založeny na respektování odborných kvalit a na uvědomování si toho, že dobře fungující škola je vzájemně propojený organismus, nikoli jen souhrn jednotlivců. $\mathrm{V}$ tomto smyslu pak kolegialita představuje podmínku funkční spolupráce mezi vyučujícími, která zahrnuje nejen společné plánování a př́ípravu aktivit, ale také vzájemné sdílení zkušeností (Ning, Lee \& Lee, 2012).

Harrisová \& Anthonyová (2001) rozlišují dva typy kolegiality. První se

\footnotetext{
${ }^{4}$ Formálně organizované aktivity mohou být různého druhu (školení, workshop, diskuse, profesní sdílení atd.), důležité mohou být ale i ty neformálně organizované, protože např́klad Avalos (2011) upozorňuje, že i běžný rozhovor mezi učiteli může mít rozvojový potenciál (více o tomto tématu viz kapitola Formální a neformální setkávání).
} 
týká emocionální podpory (otevřená komunikace, naslouchání, zájem mezi kolegy) a druhý profesního rưstu (odborné diskuse, společné vzdělávání a projekty). Toto pojetí navazuje na starší koncept sociální opory od Caplana (1981), který odlišoval emocionálni podporu (ventilace pocitů, morální vzpruha) a podporu instrumentální (informace, materiály a další pomoc při řešení problémů). Mezi koncepty existuje rozdíl ve vnímání důležitosti jednotlivých typů: Harrisová a Anthonyová (2001) považují oba za stejně důležité, zatímco Caplan (1981) vidí v emocionální kolegialitě určitá rizika, protože vyjadřování porozumění je sice situačně povzbuzující, ale nemotivuje $\mathrm{k}$ odstranění případných problémů. Je-li cílem školy zkvalitňování pedagogického procesu, měla by posilovat $\mathrm{v}$ učitelském sboru profesně-růstovou kolegialitu a funkční emocionální kolegialitu (Sasson \& Somech, 2015).

Z dostupných výzkumů navíc vyplývá, že kolegiální vztahy jsou pro kvalitu pedagogického procesu i pro profesní spokojenost vyučujících důležitější než osobní, přátelské vztahy. De Lima (2011) ukazuje, že učitelské kolektivy, které se spoléhají především na osobně-práatelské vztahy, vykazují slabší spolupráci, nižší flexibilitu a slabší reflexi než kolektivy, které usilují primárně o vztahy profesionálně-kolegiální. Také z českého výzkumu učitelského vyhoření vyplynulo, že ve školách $s$ kolegiálními vztahy je nižší riziko vyhoření než ve školách s negativními vztahy, ale i než ve školách $s$ přátelskými vztahy (Smetáčková \& Francová, 2020).

\section{ForMÁLNÍ A NEFORMÁLNÍ}

\section{SETKÁVÁNí}

K rozvoji kolegiality, která může být následně využívána pro efektivnější profesní rozvoj, je nezbytné, aby vyučující měli možnost trávit společně čas profesně či osobně smysluplnými aktivitami. Jarzabkowski (2002) ve svém výzkumu ukázal, že pokud mají členové učitelského sboru dostatek prŕležitostí k setkávání, výrazně to napomáhá budování komunity a zlepšování pracovní spolupráce. Sociální aktivity (např. vtipkování v kabinetu, posezení u kávy, společné sportování) umožňují učitelům, aby se vzájemně poznali a sdíleli své osobní i profesní názory, pocity a zkušenosti. Osobní i profesní sdílení vede k řadě výsledků - zmírnění akutního i dlouhodobého stresu, zlepšení komunikace, zlepšení spolupráce a prohloubení emočního závazku (Jarzabkowski, 2002; Sasson \& Somech, 2015).

Učitelská setkávání mohou ve školách probíhat bud' neformálně, nebo formálně. I přesto, že neformální setkávání mohou být pro učitele prospěšná, jejich slabinou je, že nejsou zaručena, neprobíhají pravidelně a někteří vyučující se jich neúčastní. Jejich individuální zisky se tak nemusí promítnout do zvyšování kvality celé školy, resp. celého učitelského sboru.

Formální setkávání naopak představují aktivity organizované obvykle vedením školy s náplní danou pracovními tématy. Leonard \& Leonardová (2003) vytvořili výčet nejčastěji se vy- 
skytujících setkání, které předpokládají učitelskou spolupráci nebo $\mathrm{k}$ ní mají směřovat. Zahrnuli do něj porady učitelského sboru, speciální vzdělávací porady, porady ohledně učiva, společné plánování hodin apod. Účelem vyjmenovaných setkání je většinou předávání informací a osvojování nových profesních znalostí či dovedností. Tato setkání jsou obvykle pravidelná a povinná. Sdílení profesních zkušeností v rámci nich může potenciálně probíhat, ale ne vždy je to možné a nebývá to jejich primárním účelem. Méně frekventované pak jsou intervize, supervize, balintovské skupiny, př́padové konference a další typy setkávání, které „pouze“ poskytují prostor pro sdílení mezi vyučujícími (Leonard \& Leonard, 2003). ${ }^{5}$

\section{SKUPINOVÉ PROFESNÍ SDÍLENí}

\section{A JEHO PŘíNOSY}

Právě formální skupinové sdílení zkušeností se na základě dostupných výzkumů jeví jako velmi př́nosné pro profesní rozvoj učitelů. Především proto, že komunikace s kolegy pomáhá učiteli lépe reflektovat (tedy učinit vlastní praxi předmětem kritického myšlení; Svendsen, 2016) a inspirovat se názory a pohledy ostatních (Glazer et al., 2004). Je mnoho forem, které může učitelské skupinové sdílení mít - např. výše zmiňovaná supervize, intervize nebo třeba v zahraničí používané profesni reflektivni skupiny (Glazer et al., 2004), učitelské reflektivni skupiny (Farrell \& Jacobs, 2016) či učitelské studijni skupiny (Birchak et al., 1998). Každá z nich má svá specifika, a přesto můžeme najít některé společné rysy a důvody, proč se jejich zavedení do učitelské praxe jeví jako užitečné.

Pokud se vyučující setkávají s odlišnými názory a postoji během společných setkání, vzniká tenze, která je tím, co jim později umožňuje se profesně učit a posouvat dál (Simoncini, Lasen \& Rocco, 2014). Švaříček a kol. (2017) upozorňují na to, že během dostatečně reflektivních rozhovorů může dojít $\mathrm{k}$ tomu, že se názory dostanou do konfliktu a dochází $\mathrm{k}$ disonanci. Její prožitek je důležitý, protože díky němu dochází $\mathrm{k}$ hlubšímu ukotvení změny. Naopak bez toho hrozí, že by se vyučující nedokázali posouvat dál a stagnovali by ve stejných postupech a postojích. $\mathrm{K}$ takovému pocitu disonance nemohou vyučující obvykle dospět sami, stejně tak to není možné v blízké skupině podobně smýšlejících kamarádů/kolegů.

$\mathrm{Na}$ druhou stranu to přináší zvýšenou potřebu bezpečného a podporujícího prostředí, které vyučujícím umožní, aby mohli hovořit i o svých problémech a o tom, co se jim nedaří. Pokud se to podaří zajistit, může skupinové sdílení představovat důležité místo, kde vyučující mohou uvolnit nahromaděný stres, vyjádřit své emoce a zároveň se dozvědět více o sobě (jak se chovají v určité situaci, jak reagují na určité lidi). Pokud lépe

\footnotetext{
${ }^{5}$ Situace v ČR je podrobněji rozebrána v kapitole Profesní sdílení v českém školství.
} 
rozumí sami sobě, může to mít následně vliv i na rozvoj jejich profesní sebedůvěry (Birchak et al., 1998; Glazer et al., 2004; Farrell \& Jacobs, 2016; Svendsen, 2016).

Podporující skupinové setkávání navíc může vyučujícím pomoci při změně postupů a výukových metod. To je samo o sobě náročné, protože to pro učitele často představuje nejistotu, nutnost pustit se za hranice toho, co znají, a většinou také trvá delší dobu, než vidí výsledky své práce (Švaříček et al., 2017). Potřebnou podporu a povzbuzení mohou vyučujícím opět nabídnout jejich kolegové a kolegyně. Názor, že stačí učiteli ukázat a přesvědčit ho dělat věci jinak, většinou není dostačující k tomu, aby pak skutečně začal dělat věci jinak (Svendsen, 2016).

Skupinové setkávání představuje místo, kde se jedinec snaží zformulovat to, co si myslí a cítí. Pokud vyučující musí vyjádřit své myšlenky před druhými, musí je nejprve strukturovat. To znamená, že se soustředí na to, jaké prvky popisovaná zkušenost obsahuje, které z nich jsou podstatné a jaké vztahy mezi nimi panují. Zodpovědnost plynoucí z př́tomnosti ostatních je motivací, aby se vyučující pustili do reflektivního zkoumání, a to s větší pravděpodobností, než kdyby byli sami (Rodgers, 2002).

Pro úspěšné profesní sdílení je nutné, aby se vyučující cítili při setkání bezpečně. Není tedy úplně možné používat na kolegialitě založené formy profesního rozvoje $\mathrm{v}$ př́padě, že vztahy $\mathrm{v}$ učitelském sboru nefungují dobře. $\mathrm{Na}$ druhou stra- nu ale mohou podobná setkávání vztahy a kolegialitu dále posilovat. Jejich prostřednictvím vyučující získávají pocit sounáležitost s ostatními vyučujícími a přináležitosti ke škole, což se pozitivně projevuje na fungování školy jako celku (Birchak et al., 1998; Glazer et al., 2004). Schopnosti, jako je naslouchání, akceptace, citlivost na jedinečné potřeby druhých atd., které během profesního sdílení vyučující rozvíjejí, pak mohou předat i svým žákům, čímž se zkvalitňuje pedagogický proces (Birchak et al., 1998).

\section{Negativa PROFESNÍHO SDÍlENí ZKUŠENOSTÍ}

Během formálních setkání zaměřených na sdílení se může objevovat neochota či obavy (části) vyučujících z otevřeného sdílení. Sdílení je založeno na (sebe)reflexi, $\mathrm{k}$ níž musí být vyučující ochotni a př́ipraveni. Dále, jak upozorňují Lazarová a Prokopová (2004), je nutné ve škole i při konkrétních setkáních vytvořit bezpečné prostředí plné důvěry, protože bez toho reflexe práce a spolupráce $s$ kolegy téměr není nemožná. Kvůli obavám z reakce ostatních (popř. kvůli nezájmu o názory druhých) se vyučující mohou před sdílením uzavřít. Obavy mohou plynout i z osobních střetů a negativních důsledků pro pracovní vztahy. Vyučující se mohou cítit zastrašeni osobností některých kolegů nebo mají obavy sdílet své slabiny a pochybnosti (to se může týkat především začínajících 
vyučujících; Hoffman-Kipp, Artiles, \& Lopez-Torres, 2003; Glazer et al., 2004; Simoncini et al., 2014).

Vedle obavy z nedostatečného bezpečí a důvěry Leonard a Leonardová (2003) ve svém výzkumu identifikovali následující potíže: respektování úzu, že v učitelství jsou př́mo na pracovišti vykonávány jen ty pracovní povinnosti, které souvisí $s$ výukou; příliš velká únava a zaměstnanost; přehlcenost jinými pracovními povinnostmi; nedostatečný závazek k práci; demotivující kolegové, kteří odmítají novinky; absence finanční odměny jako kompenzace za čas. $\mathrm{V}$ uvedených důvodech převládají ty, jejichž společným jmenovatelem je slabé přesvědčení vyučujících, že kolegiální vztahy a spolupráce jsou důležité a že součástí učitelské profesionality by měl být jejich rozvoj. Marshall (2005) označuje za př́čcinu slabou kulturu škol a roli kolegiality v ní. Aby došlo ke změně, považuje za nutné, aby byl zajištěn čas pro profesní setkávání, zařazení pravidelného hodnocení v učitelských týmech a formulování vize školy, ze které by bylo jasné, o jaký typ výuky a spolupráce škola usiluje.

$\mathrm{Na}$ postoj ke sdílení mají vliv i očekávání, která jsou se setkáváním spojena. Očekávání jsou závislá na tom, jak je téma ve škole komunikováno, jaké s ním vyučující mají asociované zkušenosti a jaké jsou konkrétní organizační podmínky setkávání (Torff \& Sessions, 2008). Ty zahrnují čas, formu účasti, složení skupiny atd.
Zásadní vliv na vytváření organizačních i hodnotových podmínek a zavedení efektivních učitelských setkávání tak má vedení škol. Bredeson (2000) na základě svého výzkumu formuloval pro vedení škol následující doporučení: poskytnout vyučujícím čas a prostor pro setkávání; nasměrovat učitele na možnosti profesního rozvoje a zhodnocovat průběžně jeho výsledky; vyvarovat se nadměrného vlivu a uplatňovaní moci; posouvat vyučující $\mathrm{k}$ větší autonomii a nezávislosti.

Důležitou otázkou pro vedení školy, ale i samotné vyučující je povinná či nepovinná účast na sekáních. Někteří autoři (např. Birchak et al., 1998) zastávají názor, že účast na profesním sdílení zkušeností by měla být vždy dobrovolná, protože je důležité, aby učitelé sami chápali, že nesou zodpovědnost za svůj rozvoj. $\mathrm{Na}$ druhou stranu však dobrovolná účast může vytvářet vícekolejnost $\mathrm{v}$ profesním rozvoji učitelského sboru, protože se obvykle dobrovolně účastní ti, kteří mají zájem o profesní růst i v ostatních oblastech, zatímco druhá část vyučujících zůstává ve své pasivitě (McComb \& Eather, 2017). Pokud je setkávání součástí pracovní doby (což by bylo ideální), je pochopitelné, že vedení chce udělat účast povinnou. Možným řešením, které nenaruší autonomii a zodpovědnost vyučujícího, je v takovém prrípadě dát mu jinou možnost jak se vzdělávat (individuálně, ve dvojici aj.; Birchak et al., 1998). 


\section{Profesní SDílení V ČESKÉM ŠKOLSTVÍ}

Výše uvedené výzkumy pocházejí převážně ze zahraničního prostředí a tedy i z odlišných vzdělávacích systémů. Jeví se proto jako velmi důležité prozkoumat skupinové sdílení v českém prostředí, kde postupně začíná toto téma získávat více pozornosti.

Již před 15 lety si Lazarová a Prokopová (2004) všímaly, že v českém prostředí se objevuje velké množství nových metod podporujících rozvoj učitelů a mezi nimi i aktivity založené na spolupráci $\mathrm{v}$ rámci školy, supervize nebo diskusní skupiny. Jejich širší využívání ve školách se však nedařilo (např́klad ani u mentoringu, jak zmiňuje Lazarová, 2005b). O dekádu později se situace př́iliš nezměnila, jak dokládá Michek (2016), který uvádí, že přibližně $70 \%$ vyučujících $\mathrm{z}$ jeho výzkumu využívá spíše jednodušší rozvojové aktivity, které nevyžadují spolupráci s kolegy (např̀ samostudium, jednodenní školení, didaktické materiály), naopak pouze $10 \%$ využívá komplexnější metody, ${ }^{6}$ jako je např́iklad videonahrávka a její analýza, hospitace $\mathrm{v}$ jiné škole nebo supervize.

Důvodem může být to, že vyučující vnímají další vzdělávání především jako získávání znalostí a dovedností uplatni- telných ve výuce, podstatně méně už si s tím spojují změny v myšlení, postojích nebo sebehodnocení (Lazarová \& Prokopová, 2004; Píšová et al., 2013). Témata, která tak vyučující v rámci dalšího vzdělávání chtějí řešit, se týkají hlavně práce se žáky a technikou, didaktických postupů apod. Nicméně Lazarová a Prokopová (2004) na konci tohoto výčtu uvádějí i komunikaci s lidmi nebo spolupráci s kolegy, takže je zřejmé, že si (někteří) vyučující uvědomují, že je nutné pracovat i na jiných tématech kromě těch přímo souvisejících s výukou.

Další príícinou malého využívání profesního sdílení v českých školách může být nedostatečná informovanost pedagogů a nezkušenost s těmito novými formami práce (Lazarová \& Cpinová, 2004). Pokud s tím vyučující (ale také vedení) nemají zkušenosti, je možné, že si ani neumí úplně představit, proč by podobné aktivity měly být prospěšné a jak by jim společná reflexe a diskuse mohla pomoci v profesním rozvoji.

Navíc velká část vyučujících považuje další vzdělávání (kam patří i profesní sdílení) za něco, co je spíše zátěží a zvyšuje jejich únavu (konkrétně $40 \%$ podle výsledků Lazarové, 2005b), nejsou $\mathrm{k}$ němu motivováni (38\% podle Michka, 2016). Stejně jako v jiných oblastech školního života i zde může hrát roli ne-

$\overline{{ }^{6}}$ Je důležité zmínit, že uvedený výzkum zahrnuje velké množství rozdílných aktivit (celkem 32), které nejsou zcela porovnatelné. Je tedy náročné výsledky zevšeobecnit, není zcela jasné, o čem uvedených $10 \%$ vypovídá, protože je do toho zřejmě zahrnuto více rozdílných aktivit. Co se týká konkrétně profesního skupinového sdílení (není však uvedeno, zda jsou aktivity myšleny skupinově nebo individuálně), tak supervizi (29. místo ze 32) využilo 6,5-12,5\% vyučujících (rozptyl je dán rozdíly mezi stupni škol) a mentoring (20. místo) využilo $10-25,5 \%$ vyučujících. 
dostatek času a financí. Navíc skupinové sdílení (na rozdíl např́klad od školení ke konkrétnímu učivu či didaktickému postupu) přináší velké nároky na pocity bezpečí a důvěry vyučujících ve škole.

\section{Představení vízKumu}

Výše zmiňujeme prŕpadné pozitivní dopady profesního sdílení, řada výzkumů však ukazuje, že není snadné efektivní profesní sdílení ve školách prosadit (Hoffman-Kipp et al., 2003), a to i přesto, že se jedná o země, kde je tradice skupinového učitelského setkávání historicky silnější a aktuálně podporovaná stávající legislativou. V České republice, která se nevyznačuje silnou tradicí diskurzu učitelské kolegiality ani učitelské sebereflexe, vnímáme v posledních dvou dekádách postupné zesilování požadavků jednak na spolupráci a kolegialitu mezi vyučujícími a jednak na zahrnutí sebereflexe do cílů profesního rozvoje (srov. Lazarová, 2005a; Starý et al., 2012; Píśová et al., 2013).

$\mathrm{V}$ našem výzkumu jsme si kladli za cíl zjistit, zda vyučující využívají organizované sdílení profesních zkušeností v rámci učitelských sborů na svých školách a jak je hodnotí. Zde prezentovaná analýza se zaměřuje na výsledky dotazníkového šetření mezi vyučujícími regionálního školství. Účelem dotazníkového šetření bylo zmapovat frekvenci zkušeností s profesním sdílením (a to obecně, nikoli jen četnost specifických technik) a základní očekávání a postoje vůči němu.?

Protože byly oslovovány školy bez ohledu na to, zda využívají specifické formy a techniky profesního sdílení (např. supervize), bylo nutné použít obecnější označení. Dotazník tak pracoval s pojmem profesní sdílení, které bylo charakterizováno jako setkáni pedagogického sboru (naprr. supervize), jejichž účelem je, aby jednotlivi vyučujici hovorili o svých ucitelských zkušenostech, pocitech a problémech. Toto obecné vymezení může zahrnovat supervizi, intervizi, mentoring nebo konkrétní techniky, jako je Wanda či balintovské skupiny. $\mathrm{Na}$ některých školách však může být takto vymezené sdílení součástí porad či školení, pokud záměrně obsahují část zaměřenou na sdílení zkušeností (a nikoli pouze jednosměrné informování).

Ve vztahu $\mathrm{k}$ dotazníkovému šetření jsme si kladli následující výzkumné otázky: 1. Jaká je míra zkušeností vyučujících se setkáváním, které zahrnuje sdílení profesních zkušeností? 2. Jaké jsou organizační podmínky takového

\footnotetext{
${ }^{7}$ Vedle dotazníkového šetření jsme ve výzkumu "Supervize - prevence učitelského vyhoření (finančně podpořen TAČR TL01000399) realizovali sérii prrípadových studií na školách, které využívaly konkrétní formu profesního sdílení zkušeností, nejčastěji se jednalo o supervizi, intervizi či mentoring, v některých případech byly používány konkrétní techniky Wanda či balintovské skupiny. Případové studie využívaly následující metody sběru dat: pozorování kolegiálních setkávání, rozhovor $\mathrm{s}$ ředitelkou/ředitelem školy, rozhovor $\mathrm{s}$ vedoucí osobou kolegiálního setkávání, dotazníkové šetření v učitelském sboru a rozhovory s vybranými vyučujícími. Výsledkům př́padových studií se v tomto textu nevěnujeme.
} 
setkávání? 3. Jaké přínosy v takovém setkávání vyučující spatřují? 4. Jaké překážky v organizaci takového setkávání vyučující spatřují?

\section{VÝZKUMNÝ NÁSTROJ}

\section{A METODOLOGIE}

Dotazník obsahoval 20 položek, z toho šest bylo identifikačních a týkaly se stupně školy, velikosti školy, délky praxe, pracovní pozice, věku a pohlaví. Dalších 14 se vztahovalo k samotným učitelským setkáváním, jejichž účelem nebo alespoň součástí je sdílení profesních zkušeností. Otázky se týkaly existence takových setkávání, jejich frekvence $\mathrm{v}$ průběhu školního roku, formy účasti (dobrovolná či povinná) a přítomnosti vedení. Těžištěm byly tři položky, které se zaměřovaly na vnímané přínosy a překážky organizace profesního sdílení. Specificky se zjištovalo, zda sdílení probíhá formou supervize, intervize či mentoringu. Pozornost byla věnována také obsahu sdílených zkušeností a roli školního poradenského pracoviště (specificky školního psychologa či psycholožky) v organizaci podobných setkávání.

Př́íprava dotazníku vycházela $\mathrm{z}$ kvalitativních rozhovorů na školách zapojených do prrípadových studií, které orga- nizují supervize, intervize či mentoring, a dále $\mathrm{z}$ rozhovorů $s$ vyučujícími $\mathrm{v}$ rámci výzkumu učitelského vyhoření, kde jedním z témat byla sociální opora $\mathrm{v}$ učitelském sboru a její role při zvládání profesního stresu. Při prrípravě byly využity také zahraniční i české odborné zdroje, a to zejména ve vztahu $\mathrm{k}$ př́činám ne/ ochoty vyučujících účastnit se profesního sdílení. Dotazník byl pilotován prostřednictvím osmi rozhovorů (vyučující vyplnili dotazník a poté se vyjadřovali ke srozumitelnosti jednotlivých položek i přiméřenosti celkové struktury dotazníku) a následně jednoduché kvantitativní analýzy odpovědí od 35 respondentů.

$\mathrm{Na}$ základě pilotáže bylo zpřesněno označení profesního sdílení. Zároveň se však ukázalo, že označení supervize a intervize coby specifických organizačních forem nebylo zcela známé. Proto do dotazníku byla včleněna terminologická poznámka, ${ }^{8}$ která zpřesňovala, co se těmito pojmy míní.

Dotazník byl zadáván on-line prostřednictvím aplikace SurveyMonkey. Jeho vyplnění trvalo přibližně 12 minut. Výpovědi byly anonymní. Základní analytickou jednotkou byl jedinec, nikoli škola, resp. učitelský sbor. To představuje jeden $\mathrm{z}$ limitů studie.

\footnotetext{
${ }^{8} \mathrm{~V}$ dotazníku je používáno označení supervize či intervize. Týmovou supervizí míníme pravidelná setkání učitelského sboru (či jeho části) pod vedením supervizora, který vytvárí bezpečné prostředí a specifickými strategiemi podporuje vzájemné sdílení zkušeností mezi vyučujícími. Smyslem supervizí je hovořit o svém chování a pocitech v různých profesních situacích. Smyslem supervize není hodnotit a kontrolovat učitelský sbor a jednotlivé vyučující, ale posilovat jejich profesní kompetence a sebevědomí. V případě vyspělého učitelského týmu může supervize být (částečně) nahrazena týmovou intervizí, která předpokládá obdobné cíle a postupy, avšak bez vedení supervizora.
} 
Tab. 1. Složení výzkumného souboru z hlediska stupně a typu školy

\begin{tabular}{|l|c|c|}
\hline MŠ & 864 & $36,3 \%$ \\
\hline ZŠ - pouze 1. stupeň & 220 & $9,3 \%$ \\
\hline ZŠ - 1. a 2. stupeň & 613 & $25,8 \%$ \\
\hline Víceleté gymnázium & 64 & $2,7 \%$ \\
\hline Gymnázium & 84 & $3,5 \%$ \\
\hline Střední odborná škola & 206 & $8,7 \%$ \\
\hline Střední odborné učiliště a odborné učiliště & 83 & $3,5 \%$ \\
\hline Neuvedlo & 243 & $10,2 \%$ \\
\hline
\end{tabular}

Získaná data byla analyzována základními statistickými procedurami, které vedle deskriptivních statistik zahrnovaly testování rozdílů (t-test o shodě průměrů a ANOVA) mezi podskupinami respondentů podle typu školy a podle existence zkušeností se setkáváním zahrnujícím sdílení profesních zkušeností. V případě otázek $s$ otevřenými odpověd'mi byly použity postupy kvantitativní obsahové analýzy nebo v případě položek $s$ menším počtem odpovědí také otevřené kódování10 (Mayring, 2004).

\section{VÝZKUMNÝ SOUBOR}

Informace o dotazníkovém šetření a žádost o jeho vyplnění byla rozeslána na všechny školy registrované v rejstř́ku škol. Seznam škol jsme získali na požádání od Ministerstva školství, mládeže a tělovýchovy. Vzhledem k existenci odlišných podmínek i podpůrných mechanismů ze stran zřizovatelů i ministerstva $^{11}$ jsme předpokládali možné rozdíly mezi školami, a proto byly do výzkumu zahrnuty školy různých stupňủ a typů.

Sběr dat probíhal od listopadu 2018 do února 2019, tedy po dobu třech měsíců ve školním roce 2018/2019. Odpovědi byly získány od 2377 osob. Složení souboru z hlediska stupně a typu školy nabízí tabulka 1 . Z ní vyplývá relativní vyváženost mezi zapojením vyučujících z mateřských, základních a středních škol (podíl osob ze středních škol je nižší, avšak dostatečný na to, aby bylo možné

\footnotetext{
$\overline{{ }^{9} \text { Analytický postup detekující frekvenci klíčových slov a jejich ekvivalentů. Byl použit u otevřených položek }}$ s úzkou odpovědí. Celkově se jednalo o položky zodpovězené 700-1 200 respondenty.

${ }^{10}$ Otevřené kódování bylo využito u položek zodpovězených menším podílem respondentů. Zejména se jednalo o položky k průběhu supervize coby specifické techniky kolegiálního sdílení, s níž mělo zkušenost zhruba jen 100 osob. Odpovědi byly poměrně malého rozsahu.

${ }^{11}$ Podpůrnými mechanismy máme na mysli možnosti financování setkání z ESF. Takzvané šablony dovolovaly žádat o financování supervizních setkání v mateřských školách výrazně dřive než v základních školách. Existence nabídky má facilitující efekt ve dvou směrech: 1. školy si mohou službu dovolit, protože na ni získaly finance; 2. školy jsou konfrontovány s existencí dosud málo známé služby, o níž si mohou získávat informace a zkoušet její prínosnost pro vlastní instituci.
} 
provádět statistická srovnání). Výzkumný soubor však nebyl reprezentativní, což představuje další limit výzkumu. Při sběru dat nebylo možné kontrolovat, které ředitelky a ředitelé škol přeposlali naši výzvu vyučujícím na své škole, ani to, kteří vyučující se nakonec rozhodli dotazník vyplnit. Vzhledem k samovýběru respondentek a respondentů tak mělo šetření formu ankety.

\section{VÝSLEDKY}

$\mathrm{Z}$ odpovědí vyplynulo, že $43 \%$ respondentů působí na školách, kde se pravidelně pořádají setkání učitelského sboru, jejichž účelem je sdílení učitelských zkušeností. ${ }^{12}$ Jedním typem těchto setkání může být i učitelská supervize, kterou zažívala 4,5\% vyučujících, nebo intervize, kterou zažívalo $1 \%$ vyučujících. Respondenti s těmito zkušenostmi charakterizovali konkrétní setkání např́klad takto: Sdileni zkušenosti pri řšseni konfliktnich situaci se zákonnými zástupci dètí, príp. pèstouny; Kolečko sdíleni, rozebráni situace $v$ jedné konkrétni třidè, předáni zkušeností jednoho z učitelì na téma práce se žáky ve skupinách. ${ }^{13}$ Až čtvrtina respondentů $(24,6 \%)$ používala pro taková setkání označení porady. Nejednalo se však o porady ve smyslu jednosměrného předávání organizačních informací ze strany vedení $\mathrm{k}$ podřízeným, nýbrž vždy bylo důležité aktivní zapojení vyučujících, vzájemné předávání zkušeností a zaměření na hlubší pedagogická témata. Taková setkání byla popisována takto: Vyučujici matematiky srovnávali hodnoceni žáku $v$ jednotlivých ročnicich a porovnávali výsledky žákỉ, kteři se uči podle Hejného a klasickým zprisobem; Evaluace dèti, kompetence dètí, externi supervize pedagogü. V charakteristikách porad absentovala běžná provozní témata, která mají být ,jen“ vyslechnuta, ale neposkytují prostor pro diskusi, nebot' se nepředpokládá individuální rozdílnost pohledů. To by byl př́ípad tradičních porad, kdy vedení školy či jím delegovaná osoba sděluje určité informace organizačního charakteru. Podle části respondentů setkání na jejich školách nemají ustálené označení (7,6\%), ale přesto jsou organizována a dochází v rámci nich ke sdílení zkušeností mezi vyučujícími. Naopak více než polovina vyučujících (57\%) neměla možnost se na své škole účastnit žádného typu profesního setkávání zaměřeného na sdílení.

$\mathrm{Na}$ školách, kde setkání probíhají, se podle respondentů nejčastěji konaly 4 krát ročně $(33 \%)$ nebo více než $7 \mathrm{krát}$

\footnotetext{
$\overline{{ }^{12}}$ Znění uzavřené otázky: Organizujete na vaši škole oficiálni setkání pedagogického sboru (např̀ supervize), jejichž úcelem je, aby jednotlivi vyučujicí hovorili o svých učitelských zkušenostech, pocitech a problémech? Pokud se na škole setkání organizují, byla položena polouzavřená otázka: Jak označujete setkáni, jejichž účelem je kolegiální sdílení zkuseností, pocitů a problémů? Respondenti vybírali mezi následujícími odpověd’mi: supervize, intervize, porada, nemáme ustálené označení, jiné označení (doplňte jaké).

${ }^{13}$ Tyto a následující odpovědi týkající se průběhu setkávání byly uváděny v otevřené otázce následujícího znění: Můžete prosim stručně popsat, jak probihalo a co bylo obsahem posledního setkáni?
} 
ročně (32\%). V $21 \%$ pak 5-6krát ročně a v $15 \%$ jen $1-2$ krát ročně. Frekvence 5-6, př́ípadně 4 setkání za rok odpovídá doporučované frekvenci supervizí či intervizí. Podle $33 \%$ respondentů jejich školy spolupracují s externisty, kteří profesní setkání vedou. Naopak dvě třetiny respondentů uvedly, že setkání jsou vedena někým ze školy, a to bud' př́mo osobou z vedení, nebo méně často osobou ze školního poradenského pracoviště.

Důležitým organizačním aspektem, který může mít dopad na postoj vyučujících ke sdílení i na jeho efektivitu, je forma účasti na setkáních. Jako zcela dobrovolná byla setkání organizována na školách $31 \%$ respondentů, naopak jako zcela povinná na školách $56 \%$ respondentů. V př́ípadě $13 \%$ respondentů je dobrovolnost setkávání proměnlivá, a to bud' pro část učitelského sboru ( $\mathrm{tj}$. někteří vyučující se účastnit nemusí, zatímco jiní ano), nebo v některých termínech (tj. vání v některých termínech je povinné, zatímco v jiných dobrovolné).

\section{PřínOSY A VÝHOdY}

Těžištěm dotazníkového šetření byla položka týkající se přínosů profesního sdílejícího setkávání ve školách. Respondenti odpovídali na následující otázku: $V$ čem spočivaji podle Vás hlavni výhody podobných setkáni? Vycházejte prosim ze svých zkušeností se supervizi ci podobnými setkáními, nebo ze své predstavy o nich. $U$ každé popsané výhody prosim označte, jak duiležitá je právě pro Vás. V položce bylo předloženo osm tvrzení o možných př́nosech setkávání v oblasti znalostí, emocí, klimatu a vize. Jednotlivá tvrzení uvádí tabulka 2. Vyučující hodnotili každé tvrzení na pětibodové škále, od 1 (nedůležité) po 5 (velmi důležité). Jednotlivá tvrzení dosáhla průměrného hodnocení 4,03-4,48. To znamená, že všechny uvedené př́ínosy jsou respondenty vnímány jako značně důležité. Mírně větší důležitost přisuzují přínosům v oblasti motivace a vize oproti přínosům v oblasti informací a znalostí.

Tabulka 2 uvádí průměrné hodnocení důležitosti jednotlivých př́nosů mezi respondenty, kteří měli přímé zkušenosti se setkáváním za účelem profesního sdílení, a těmi, na jejichž školách se podobné setkávání neorganizovalo. U všech tvrzení obě skupiny vyučujících hodnotí zmíněný přínos jako spíše důležitý či velmi důležitý; směr hodnocení je tedy shodný. Ovšem přesto průměrné hodnocení jednotlivých tvrzení od vyučujících se zkušeností a bez zkušenosti s profesním setkáváním vykazují statisticky významný rozdíl ( $\mathrm{p}<0,001)$. Ti, kteří mají zkušenost se setkáváním za účelem profesního sdílení (bez ohledu na to, jak toto setkávání označují), hodnotili všechny př́nosy setkávání ve všech aspektech jako vyšší, resp. důležitějšíi. Předpokládáme tedy, že prrímá zkušenost přesvědčuje vyučující o smysluplnosti a pozitivních efektech učitelského setkávání.

Ve světle uvedených výsledků není překvapující, že $61 \%$ respondentů ze škol, kde setkávání za účelem profesního sdílení neprobíhá, by měla zájem o jeho 
Tab. 2. Př́nosy a výhody profesního setkávání, průměrné hodnocení podle zkušenosti se sdílením

\begin{tabular}{|l|c|c|}
\hline \multirow{2}{*}{ Hodnocený př́nos/výhoda } & \multicolumn{2}{|c|}{ Setkávání } \\
\cline { 2 - 3 } & ano & ne \\
\hline Ukázat si konkrétní didaktické postupy pro výuku určitých témat & 4,12 & 3,94 \\
\hline Předat si nové informace (o doporučených postupech, legislativě apod.) & 4,29 & 4,04 \\
\hline Ujistit se, že nejsem jediný/á, kdo zažívá v učitelství nejistoty a problémy & 4,37 & 4,15 \\
\hline Ukázat si konkrétní postupy, jak zvládat problematické chování žáků & 4,42 & 4,27 \\
\hline Prohloubit vzájemný respekt a porozumění uvnitř pedagogického sboru & 4,58 & 4,22 \\
\hline Inspirovat se v tom, jak přistupovat k obtížným situacím & 4,6 & 4,28 \\
\hline Vzájemně se povzbudit a motivovat & 4,69 & 4,33 \\
\hline Budovat společnou vizi a jednotný přístup uplatňovaný v naší škole & 4,62 & 4,29 \\
\hline
\end{tabular}

Výroky byly hodnoceny na škále $1-5(1=$ neduiležité, 5 = velmi dưležité $)$

zavedení. Naopak jen $22 \%$ by o jeho organizaci zájem nemělo a $17 \%$ není rozhodnuto.

Respondenti, kteří byli v pozici ředitele školy nebo zástupce, hodnotili čtyři tvrzení signifikantně pozitivněji než respondenti z řad běžných vyučujících. Konkrétně se jednalo o př́nosy sdílení pro budování společné vize $(\mathrm{p}<0,001)$, získávání nových informací $(\mathrm{p}<0,05)$, ocenění a motivace $(\mathrm{p}<0,01)$ a porozumění a respektu $(\mathrm{p}<0,001)$.

\section{PřEKÁŽKY A NEVÝHODY}

Dalším cílem dotazníku bylo zmapovat, jaké slabiny profesního setkávání vyučující vnímají. Na základě rozhovorů a dostupné literatury bylo formulováno osm tvrzení, která popisují případné překážky a nevýhody setkávání (tab. 3). Jednotlivá tvrzení byla opět hodnocena na pětibodové škále od 1 (nevýznamná překážka či nevýhoda) do 5 (velmi významná překážka či nevýhoda). Průměrné hodnocení variovalo mezi 2,4 a 3,5. To znamená, že žádná z překážek nebyla dominantně vnímána jako zcela významná. Relativně větší slabiny respondenti spatřovali v nedostatku financí, zahlcení jinými úkoly a obavách ze sdílení potíží.

$S$ ohledem na to, zda vyučující mají přímou zkušenost $s$ profesním setkáváním zaměřeným na sdílení, se může vnímání překážek a nevýhod měnit. Provedli jsme proto opět srovnání odpovědí těchto dvou podskupin. Průměrné hodnocení $\mathrm{v}$ obou skupinách uvádí tabulka 3. Ve všech tvrzeních byl zjištěn statisticky významný rozdíl ( $\mathrm{p}<0,001)$. Vyučující bez zkušenosti se setkáváním hodnotili překážky jako významnější než ti, kteří setkávání znali. Rozdíl v důležitosti překážek byl navíc větší u nevýhod organizačního 
Tab. 3. Překážky a nevýhody profesního setkávání zaměřeného na sdílení, průměrné hodnocení

\begin{tabular}{|l|c|c|}
\hline \multirow{2}{*}{ Hodnocená překážka } & \multicolumn{2}{|c|}{ Setkávání } \\
\cline { 2 - 3 } & ano & ne \\
\hline $\begin{array}{l}\text { Nedostatek financí pro zapojení externích spolupracovníků (supervizorů) } \\
\text { kteří by setkání vedli }\end{array}$ & 3,28 & 3,64 \\
\hline Obava pedagogo̊ mluvit o svých nejistotách a problémech & 2,89 & 3,44 \\
\hline Příliš mnoho jiných povinností (kolegům nezbývá čas na setkávání a sdílení) & 3,33 & 3,99 \\
\hline Nikdo ve škole nemá čas na organizování podobných setkání & 2,65 & 3,48 \\
\hline Pochybnosti pedagogů o užitečnosti a př́nosu těchto setkání pro jejich vlastní práci & 2,60 & 3,20 \\
\hline Neochota pedagogů dávat si tipy na zvládání nejistot a problémů & 2,47 & 3,00 \\
\hline Nezájem pedagogů o názory druhých & 2,29 & 2,70 \\
\hline Špatné vztahy v pedagogickém sboru & 2,24 & 2,52 \\
\hline
\end{tabular}

Výroky byly hodnoceny na škále 1-5 (1 = nevýznamné, 5 = velmi významné)

charakteru, jako je nedostatek financí a nedostatek času.

Odpovědi respondentů nevykazovaly signifikantní rozdíl $s$ ohledem na zastávanou pozici. Jenom $\mathrm{v}$ př́padě dvou tvrzení bylo průměrné hodnocení od běžných vyučujících a od vedení škol významně odlišné. Konkrétně se jednalo o špatné vztahy ve sboru, které vyučující považovali za větší překážku než vedení škol ( $\mathrm{p}<0,01)$, a dále o nedostatek financí, který naopak představoval větší bariéru pro vedení škol než pro vyučující $(\mathrm{p}<0,05)$.

\section{Supervize}

Specifickým př́padem profesního sdílejícího setkávání jsou supervize vedené externím, vyškoleným supervizorem.
Podoba supervizí je ustálená, přesně daná vzděláním supervizorů i kontrolními mechanismy. Navíc podstatou supervizí je právě a výhradně sdílení profesních zkušeností a pocitů, které v jiných typech setkávání mohou být jen dílčím cílem. Uvedené důvody nás vedly $\mathrm{k}$ tomu, abychom srovnali hodnocení př́nosů setkávání od vyučujících, kteří se účastní supervizních setkání, s hodnocením od vyučujících, kteří mají zkušenost $s$ jinými typy setkávání, a dále $s$ těmi, kteří zkušenost s podobnými akcemi vůbec nemají. ${ }^{14}$

Př́nosy týkající se získávání nových informací a sdílení didaktických postupů, které tedy směřují do oblasti profesních znalostí, byly hodnoceny vyučujícími, kteří procházejí supervizí, jako méně důležité $(\mathrm{p}<0,01)$. Oproti tomu všechny

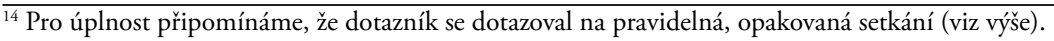


ostatní přínosy byly těmito vyučujícími hodnoceny jako důležitější $(\mathrm{p}<0,001$ a $\mathrm{p}<0,05)$. Nejsilnější rozdíl byl zjištěn u prŕnosů, které se týkají normalizace špatných zkušeností, vzájemné inspirace, vzájemného porozumění a budování společné vize - tyto prŕnosy hodnotili vyučující, kteří procházejí supervizí, jako signifikantně důležitější než ostatní vyučující.

Podobně také existovaly rozdíly mezi vyučujícími, kteří procházeli supervizí, a ostatními v př́padě nevýhod a překážek. Zde se však ukázal odlišný vzorec než $\mathrm{v}$ prŕpadě hodnocených pozitiv, které supervidovaní vyučující vnímali jako silnější než další dvě skupiny vyučujících. Vyučující procházející supervizí považovali negativa za méně či stejně závažná jako vyučující, kteří setkávání ve svých školách vůbec nezažívali. Zároveň však supervidovaní vyučující vnímali řadu negativ jako silnějších než vyučující, kteř́i se účastnili jiných forem setkávání ( $\mathrm{p}<0,05$ a $\mathrm{p}<0,001)$.

Výjimku tvořily dvě překážky, a to nedostatek času pro organizaci a př́liš mnoho jiných povinností, které vyučující procházející supervizí vnímali jako méně závažné než ostatní dvě skupiny vyučujících. Naopak prekážky související s pochybnostmi o užitečnosti setkávání, s obavami ze sdílení problémů a se špatnými vztahy mezi vyučujícími vnímali vyučující procházející supervizí jako silnější než vyučující, kteří se účastnili jiné formy setkávání. $Z$ toho vyplývá, že supervize sice přináší pro účastníky subjektivně silná pozitiva, ale současně je organizačně náročnějšśi a více závislá na klimatu ve škole.

\section{DiSKUSE}

Ve světle současných požadavků na podobu školního vzdělávání i poznatků týkajících se učitelského rozvoje je nezbytné odpoutat se od tradiční představy učitelství jako individualizovaného až osamělého povolání. Zároveň je třeba rozširíit metody učitelského profesního rozvoje tak, aby nejen zahrnoval osvojování nových znalostí, ale aby také umožňoval vyučujícím sdílet své zkušenosti, verbalizovat své pocity z výkonu profese (včetně pochybností) a reflektovat své postupy ve společnosti dalších kolegů. Důvody pro to jsou dva: 1. Profesní sdílení zkušeností pomáhá rozvíjet sebereflexi, která představuje nutnou součást profesionality. 2. Sdílení pomáhá posilovat kolegiální vztahy a spolupráci v učitelském sboru.

Michek (2016) hovoří o tom, že mezi českými vyučujícími jsou metody, které vyžadují vyšší míru spolupráce (využilo $10 \%$ respondentů), mnohem méně využívané oproti těm jednodušším (využilo $70 \%$ respondentů). V porovnání $s$ tím naše výzkumné šetření ukázalo, že $s$ nějakou formou profesního sdílení má zkušenost téměř polovina zapojených vyučujících (43\%). Rozdíl může být dán tím, že do našeho výzkumu byly zařazeny i nepojmenované techniky, které zahrnují nějaký způsob sdílení.

Lze předpokládat, že pokud takové jasné označení chybí, odráží to určitou 
nesystémovost či neukotvenost techniky v profesním rozvoji, který se na dané škole podporuje. Proto na základě našeho výzkumu považujeme za důležité, aby došlo k etablování nejen samotných technik sdílení, ale také jejich správného označování a odlišování od zavedených typů setkávání s jiným účelem, jako jsou např́klad porady.

Pouze malá část vyučujících v našem výzkumu se účastní supervize nebo intervize coby jasně pojmenovaných postupů/technik (4,5\% supervize a $1 \%$ intervize). Naopak Michkův výzkum (2016) ukázal poměrně vyšší výskyt, supervizi podle něj využilo $6,5-12,5 \%$ vyučujících (rozptyl je dán rozdíly mezi stupni škol). Důvodem tohoto rozdílu může být zařazení jak individuální, tak skupinové supervize $\mathrm{v}$ jeho výzkumu (není jasně specifikováno), zatímco náš výzkum zahrnoval pouze skupinovou supervizi, nebo tím, že náš výzkum klade důraz na určitou pravidelnost, zatímco druhý zmiňovaný zjištuje, zda metodu vyučující využili v určitém období.

Pozitivní zjištění je, že poměrně velká část vyučujících vnímá, že mají pravidelnou a vedením podporovanou př́ležitost ke sdílení profesních zkušeností v rámci učitelského sboru, které překračuje běžné povídání v rámci jejich prátelských vazeb. $\mathrm{Na}$ druhou stranu je důležité vnímat i to, že více než polovina zúčastněných vyučujících $(57 \%)$ nemá $\mathrm{k}$ pravidelnému profesnímu sdílení na své škole př́ležitost. Většina z nich (61\%) by stála o zavedení nějaké formy sdílení.
Lze tvrdit, že mírná většina vyučujících by měla o profesní sdílení zkušeností zájem (prrípadně o větší spolupráci s dalšími učiteli celkově, viz Lazarová, 2005b). K tomu je však nutné, aby na škole byly vhodné podmínky. Primárně je potřeba rozvíjet v rámci učitelského sboru pocit důvěry a podpory. $\mathrm{V}$ takovém prostředí je pak možné začít se pouštět do sdílení a reflexe s kolegy, měnit své postoje i pracovní chování (Lazarová, 2005a, 2005b). To zřejmě ani za 15 let (rozdíl mezi uskutečněnými výzkumy) není zcela vyřešené. Vzhledem $\mathrm{k}$ tomu, že obava pedagogů mluvit o svých nejistotách a problémech byla druhou nejsilněji vnímanou překážkou pro profesní sdílení, je patrné, že se stále jedná o něco, na čem je potřeba $v$ rámci učitelských sborů pracovat. Podobné výsledky ukazují i zahraniční výzkumy (Leonard \& Leonard, 2003).

Problémy s důvěrou mohou být dány i nedostatkem spolupráce a zkušeností, v takovém prípadě doporučuje napřr. Lazarová (2005b) začít u malých úkolů, aby učitelé získali dobré zkušenosti s dílčími úspěchy. Dobré vztahy a důvěra neznamenají, že všichni vyučující by se museli mezi sebou prátelit, je prŕnosné spíše rozvíjet kolegiální vztahy, které jak se ukazuje ve výzkumech - jsou pro spolupráci $\mathrm{v}$ rámci učitelského sboru (ve vztahu $\mathrm{k}$ efektivitě pedagogického procesu) důležitější než přátelství (De Lima, 2011; Smetáčková \& Francová, 2020).

Obavy a negativní nastavení mohou být důvodem, proč se na škole nedaří 
zavést některou $\mathrm{z}$ forem učitelského sdílení. Problémy spojené s profesním rozvojem vnímají čeští vyučující podobně jako v zahraničí: přehlcenost vlastní prací, nedostatek času, únava, absence finanční odměny, nízká motivace a nezájem ostatních kolegů (Hoffman-Kipp et al., 2003; Leonard \& Leonard, 2003; Lazarová 2005b; Michek, 2016). V našem výzkumu pak nejvíce vyučující souhlasili s tím, že překážkou pro profesní sdílení jsou (kromě obav ze sdílení problémů) přehlcenost prací a nedostatek financí na externí pracovníky.

Pokud však vyučující měli se sdílením už nějaké zkušenosti, vnímali tyto překážky jako méně závažné. To může být způsobeno různými důvody. Napŕíklad vyučující zjistí, že profesní sdílení a kolegialita ve sboru jsou důležité a je nutné jim věnovat více prostoru, tím pádem se začnou více snažit překonat možné překážky. Nebo si nedokážou profesní sdílení jako takové př́liš představit, protože s ním nemají zkušenosti, a poté zjistí, že reálně to není tak náročné, jak se obávali.

Pokud se podaří překonat obavy, případně negativní nastavení a úspěšně zavést některou $\mathrm{z}$ forem učitelského sdílení, jaké to má pro učitelský sbor dopady? Studie, které by prímo ověrovaly změny po zavedení profesního sdílení, dosud nemáme $\mathrm{k}$ dispozici. Př́nosné jsou však i retrospektivní studie, které zjištují, co vyučující vnímají jako přínosy profesního sdílení (např. Lazarová, 2010). Mezi ně patřila i naše studie, ve které se ukázalo, že respondenti se zkušeností s profesním sdílením považují za jeho nejdůležitější přínosy: budování společné vize, motivaci, vzájemnou inspiraci a prohlubování respektu. Tyto př́nosy můžeme ve shodě s koncepty kolegiality považovat za emočně-motivační (Harris \& Anthony, 2001). Př́nosy jako předávání informací nebo konkrétní postupy ve výuce (praktické, výukové) se ukazují také jako důležité, i když o něco méně.

Zavedením formálně organizovaného sdílení zkušeností se program profesního rozvoje na konkrétní škole může stát komplexnějším. Mohou se do něj zapojit všichni vyučující a jeho výsledek se promítne do kvality školy. Musí však být splněny určité podmínky, které spoluutvářejí nezbytný pocit bezpečí. Jedna z nich se týká formy účasti, která může být povinná, nebo dobrovolná. Náš výzkum ukázal, že většina respondentů má tato setkání vždy nebo občas povinná (69 \%). Zavedení povinné účasti může být interpretováno různě - jako absence respektu a důvěry $\mathrm{k}$ jednotlivým vyučujícím, jako snaha zbavit se organizačních problémů, které plynou $\mathrm{z}$ nepravidelných počtů zúčastněných, ale také jako signál ze strany vedení škol, že setkávání považují za důležité. Aby mohla poslední jmenovaná interpretace převážit, je nutné, aby ředitelky a ředitelé s učitelským sborem o sdílení průběžně komunikovali, představovali ho v kontextu celkového profesního rozvoje, demonstrovali význam zvolených technik, sami šli př́íkladem a určitou techniku využívali.

Někteří autoři (např. Birchak et al., 1998) se domnívají, že účast na učitelských skupinách by měla být vždy dob- 
rovolná, protože je důležité, aby učitelé sami chápali, že nesou zodpovědnost za svůj rozvoj a učení. Navíc učitelské sdílení je založené z velké části na reflexi zkušeností, a jak upozorňuje Dewey (podle Rodgers, 2002), učitel musí nejprve chtít a být prripraven reflektovat. Jinak hrozí, že bude jeho účast pouze pasivní a neefektivní. Neochota, nepřipravenost nebo neschopnost prevzít zodpovědnost za vlastní profesní rozvoj je podle Lazarové (2005b), jednou z hlavních př́ićin rezistence vůči změně.

Jednou z možností je udělat $\mathrm{z}$ učitelského sdílení povinné setkávání, alespoň dokud vyučující nezjistí, zda a jak to pro ně může být i užitečné. Jak se ukázalo v našem výzkumu, pokud mají vyučující zkušenost se sdílením, hodnotí jeho možné přínosy a výhody jako důležitější, a naopak překážky jako méně významné. Ukazuje se tedy, že prrímá zkušenost může vyučujícího přesvědčit, že sdílení je užitečné.

Studie má samozřejmě několik limitů, které je nutné zmínit. Velmi zásadním je celkově nejasné vymezení konceptu profesního sdílení, které zatím není v českém školství zcela ustálené a dochází $\mathrm{k}$ jeho zaměňování a pravděpodobně i odlišnému chápání. Ve výzkumu tak docházelo k používání pojmů, které na různých školách mohou znamenat různé věci (např. porada). Tomuto riziku jsme se snažili předcházet tím, že dotazník přesně charakterizoval, že se jedná o sdílení zkušeností, pocitů a pochybností mezi kolegy.

Jsme si také vědomi toho, že výzkumný vzorek nebyl reprezentativní a že se do výzkumu zapojili především aktivní jedinci a školy, což výsledky jistě do určité míry zkresluje (zvyšuje). V neposlední řadě je limitem i uzavřenost některých otázek v dotazníku, především $\mathrm{v}$ části týkající se výhod a nevýhod profesního sdílení; respondenti pouze hodnotili uvedené položky a nemohli napsat vlastní odpovědi. $Z$ tohoto důvodu je možné, že některé prř́nosy či překážky jsme nemuseli zjistit. Výčet tvrzení však vycházel z kvalitativních rozhovorů, které dosáhly dostatečné nasycenosti.

I přes tato omezení se domníváme, že představený výzkum přináší nové poznatky o profesním rozvoji v českých školách, jeho vnímaných pozitivních a negativních aspektech. Považujeme za důležité téma profesního sdílení zkušeností v českém školství otevírat a věnovat mu výzkumnou pozornost. Pokud se podaří nastartovat ve školách snahu o sdílení a vyučující i vedení škol pochopí jejich důležitost, může to významně posílit profesionalizaci učitelské komunity a zkvalitnit spolupráci $\mathrm{v}$ učitelských sborech.

\section{Literatura}

Avalos, B. (2011). Teacher professional development in teaching and teacher education over ten years. Teaching \& Teacher Education, 27(1), 10-20.

Birchak, B., Connor, C., Crawford, K. M., Kahn, L. H., Kaser, S., Turner, S., \& Short, K. G. (1998). Teacher study groups: Building community through dialogue and reflection. National Council of Teachers of English. 
Bredeson, P. V. (2000). The school principal's role in teacher professional development. Journal of In-Service Education, 26(2), 385-401.

Caplan, G. (1981). Mastery of stress: psychosocial aspects. American Journal of Psychiatry, $138(4), 413-420$.

Clarke, D., \& Hollingsworth, H. (2002). Elaborating a model of teacher professional growth. Teaching \& Teacher Education, 18(8), 947-967.

De Lima, J. Á. (2001). Forgetting about friendship: Using conflict in teacher communities as a catalyst for school change. Journal of Educational Change, 2(2), 97-122.

Evans, L. (2002). What is teacher development?. Oxford Review of Education, 28(1), 123-137.

Farrell, T. S., \& Jacobs, G. M. (2016). Practicing what we preach: Teacher reflection groups on cooperative learning. TESL-EJ, 19(4), 1-9.

Glazer, C., Abbott, L., \& Harris, J. (2004). A teacher-developed process for collaborative professional reflection. Reflective Practice, 5(1), 33-46.

Guskey, T. R. (2002). Professional development and teacher change. Teachers \& Teaching, 8(3), 381-391.

Harris, D. L., \& Anthony, H. M. (2001). Collegiality and its role in teacher development: Perspectives from veteran and novice teachers. Teacher Development, 5(3), 371-390.

Hoffman-Kipp, P., Artiles, A. J., \& Lopez-Torres, L. (2003). Beyond reflection: Teacher learning as praxis. Theory into Practice, 42(3), 248-254.

Jarzabkowski, L. M. (2002). The social dimensions of teacher collegiality. Journal of Educational Enquiry, 3(2), 2-20.

Kasíková, H., \& Dubec, M. (2009). Spolupráce učitelů: od větší k menší neznámé. Studia paedagogica, 14(1), 67-86.

Lazarová, B. (2005a). Osobnost učitele a rezistence vůči změně. In M. Rabušicová et al. Sborník prací Filozofické fakulty brnènské univerzity: Řada pedagogická (s. 109-122). Brno: Masarykova univerzita.

Lazarová, B. (2005b). Psychologické aspekty profesionálního rozvoje učitelů: rezistence vůči změně. Pedagogika, 55(2), 102-118.

Lazarová, B. (2010). Mentoring jako forma kolegiální podpory a strategie dobré školy. Pedagogika, 60(3-4), 254-264.

Lazarová, B., \& Cpinová, S. (2004). Kolegiální učení. K možnostem rozvoje hospitačních a supervizních setkávání učitelů. Učitelské listy, 7(3), 4.

Lazarová, B., \& Prokopová, A. (2004). Učitelé a jejich další vzdělávání: K některým psychologickým aspektům. Pedagogika, 54(3). 261-273.

Leonard, L., \& Leonard, P. (2003). The continuing trouble with collaboration: Teachers talk. Current Issues in Education, 6(15).

Marshall, K. (2005). It's time to rethink teacher supervision and evaluation. Phi Delta Kappan, $86(10), 727-735$.

Mayring, P. (2004). Qualitative content analysis. A Companion to Qualitative Research, 1(2), 159-176. 
McComb, V., \& Eather, N. (2017). Exploring the personal, social, and occupational elements of teacher professional development. Journal of Education \& Training Studies, 5(12), 60-66.

Michek, S. (2016). Využití aktivit podporujících profesní rozvoj a vnímání jejich překážek učiteli základních a středních škol. Pedagogika, 66(4), 408-426.

Ning, H. K., Lee, D., \& Lee, W. O. (2015). Relationships between teacher value orientations, collegiality, and collaboration in school professional learning communities. Social Psychology of Education, 18(2), 337-354.

Píšová, M., Hanušová, S., Kostková, K., Janíková, V., Najvar, P., \& Tůma, F. (2013). Učitel expert: jeho charakteristiky a determinanty profesního rozvoje (na pozadi výnky cizich jazykü). Brno: Masarykova univerzita.

Rodgers, C. (2002). Defining reflection: Another look at John Dewey and reflective thinking. Teachers College Record, 104(4), 842-866.

Ross, J. A., \& Bruce, C. D. (2007). Teacher self-assessment: A mechanism for facilitating professional growth. Teaching \& Teacher Education, 23(2), 146-159.

Sasson, B. D., \& Somech, A. (2015). Observing aggression of teachers in school teams. Teachers \& Teaching, 21(8), 941-957.

Simoncini, K. M., Lasen, M., \& Rocco, S. (2014). Professional dialogue, reflective practice and teacher research: Engaging early childhood pre-service teachers in collegial dialogue about curriculum innovation. Australian Journal of Teacher Education, 39(1), 27-44.

Smetáčková, I., \& Francová, V. (2020). Souvislosti mezi vnímanou kvalitou vztahů v pedagogických sborech a syndromem vyhoření u vyučujících základních škol. Studia paedagogica, 25(1), 9-32.

Starý, K., Dvořák, D., Greger, D., \& Duschinská, K. (2012). Profesní rozvoj učitelů: Podpora učitelì pro zlepšování výsledků žákủ. Praha: Karolinum.

Staempfli, A., \& Fairtlough, A. (2019). Intervision and professional development: An exploration of a peer-group reflection method in social work education. British Journal of Social Work, 49(5), 1254-1273.

Svendsen, B. (2016). Teachers' experience from a school-based collaborative teacher professional development programme: Reported impact on professional development. Teacher Development, 20(3), 313-328.

Švařiček, R., Šed'ová, K., Šalamounová, Z., \& Sedláček, M. (2017). Jak se učitelé uči: Cestou profesního rozvoje $k$ dialogickému vyučování. Brno: Masarykova univerzita.

Torff, B., \& Sessions, D. (2008). Factors associated with teachers' attitudes about professional development. Teacher Education Quarterly, 35(2), 123-133.

doc. PhDr. Irena Smetáčková, Ph.D.

Univerzita Karlova, Pedagogická fakulta, Katedra psychologie;

e-mail:irena.smetackova@pedf.cuni.cz 
Mgr. Anna Vozková

Univerzita Karlova, Pedagogická fakulta, Katedra psychologie;

e-mail:vozkova.anna@gmail.com

\section{SMETÁČKOVÁ, I., VOZKOVÁ, A. Sharing Professional Teaching Experience- the Current View in Czech Schools}

The aim of the paper is to present experience with professional sharing among teachers and to show its role in professional development. Research shows that professional sharing increases the reflection of teachers and deepens positive collegial relationships and cooperation in teaching staff. At the same time, however, there are certain barriers and negative attitudes towards it. The article presents the results of research that took place in the Czech educational environment. Its purpose was to find out what kinds of experiences Czech teachers have with sharing professional experience in groups and what advantages and disadvantages they perceive.

Methods: The research was designed as an online survey among teachers. The questionnaire includes 20 items. The request for completion was sent to all schools included in the Czech register of schools. The questionnaire was completed by 2,377 respondents. Subsequent analysis included descriptive statistics, testing for differences between subgroups based on personal experience with professional sharing, and qualitative methods such as open coding.

Results: $43 \%$ of the teachers had experience with some type of regular group sharing; only $4.5 \%$ had experience with supervision and $1 \%$ with intervision. $33 \%$ of these meetings were led by external experts and 56\% were mandatory. The biggest benefits of the meetings were mutual motivation, inspiration, and building a united vision. The main obstacles to sharing were a lack of funds, being overwhelmed with other tasks, and the fear of sharing problems.

Conclusion: The majority of the teachers involved (57\%) did not have access to professional sharing, but $61 \%$ would be interested in implementing professional sharing. In addition, personal experience with it has proved to be an important factor in assessing barriers and benefits. Teachers who had personal experience with sharing rated all the benefits as more important and the barriers as less significant.

Keywords: professional sharing, supervision, teachers, collegiality, teacher development 